\title{
Sliding Modes Strategy Implementation for Controlling Nutrition in Hydroponics Based loT
}

\author{
Septian Enggar Sukmana* \\ Politeknik Negeri Malang, Jalan Soekarno Hatta No. 9 Malang, (0341) 404424 \\ E-mail : enggar@polinema.ac.id*1, \\ *Corresponding author
}

\author{
Akmaludin Akbar, Nurul Anisa Sri Winarsih \\ Universitas Dian Nuswantoro, Jalan Imam Bonjol No. 207 Semarang, (024) 3517261 \\ E-mail : udinakmal27@gmail.com²,nurulanisasw@dsn.dinus.ac.id ${ }^{3}$
}

\begin{abstract}
To reduce unconsistenly of nutrition sensor data, an analysis which consists of mathemathical model and new control technique is required. In this paper, a simulation of smart garden is performed to simulate a smart green campus. However, the problem appears in this activity, the data form sensor is not consistent and it may harm the plant because sometime the plant may get a much nutrition and another time the plant will get less nutrition. Our propose is on the sensor circuit, we use additional circuit to our TDS meter so the data is normalized using this circuit.
\end{abstract}

Keywords - sliding mode strategy, smart garden simulation, smart green campus, internet of thing, hydroponic

\section{INTRODUCTION}

To achieve world rank status, some key factors are not only research publication and academic, but also establishment of green environment in the campus. However, to gain a green environment for campus, it needs some technical engineering in electrical, especially exploiting sensor and motor to realize the contribution of engineering and science to an environment especially to a plant [1]. Not only that, computing to process data and setting to certain action must be performed maximally and efficiently, especially when it uses cloud infrastructure [2][3]. The green environment in the campus needs to be treated technologically especially in this 4.0 industry revolution [4][5][6]. Smart green technology is the answer to face that challenge, however it does not simply as conventional one. The smart thing must be suitable for the plant which is treated automatically by that technology [2].

Internet of Thing (IOT) has been technology that is used commonly. By combining electronic sensor and computational intelligence that is operated in cloud infrastructure, treatment for the plant has to be performed optimally [1][2]. However, to gain smart thing by computational intelligence that is operated in the cloud may give wrong measure of giving water and nutrition for the plant. Each kind of plant may need different doze of water and nutrition. loT implementation for smart green campus is still less in Indonesia because of some aspect like the required technology and cost for development. Ibrahim et.al [7] has developed automatic watering control system using On-OFF method combining with fuzzy. Prathistaya [8] uses PID control to accelerate execution time from 90 days to 2 days for watering wide green area. 
Sliding modes strategy is used to regulate the water level. This technique is commonly used to convert the energy an implemented in circuit, not programming area. Not only that, this technique is also used for optimization in circuit [9].

In this paper, fuzzy sukamoto is used to enhance controlling water and nutrition. Although it is a simple implementation, but is has been a challenge to this kind of loT technology. The code must be clean and effective. Also, the activity in this paper is still just a simulation. It uses hydroponics and some electrical kit. Our object is on programming, not the hardware development although sliding mode strategy is used for water level regulation. This technique commonly used for energy converter, but it can be used for optimalization [9][10][11][12][13].

\section{LITERATURE REVIEW}

\subsection{IoT and Fuzzy Logic}

lot comes from electronics which is interacted with internet to make a something that more useful for its electronic products [2]. Usually, loT uses cloud technology especially for computing but in some basic level, computation is only performed in board. loT is consist of some activity such: a) hardware and software troublehooting, b) system administration like installation, deinstallation, and monitoring process, c) scripting, d) develop an automatic program that can perform administration system, e) interaction between machine to machine [1][3][5].

IoT must be planned carefully [7], some specific component and scheme like sensor, CPU-Memory-Interfaces, Cabling, Board, and Operating system (editor, compiler, etc) is listed in detail to make an optimum loT system. Sensor exploration must be studied well to avoid disturbance in connection between sensor and board. More important, because this system exploit internet as communication media, it needs a communication component like Message Queue Telemetry Transport (MQTT) or another kind to create a communication between machine to machine [5].

For some basic level loT, not all algorithm can be implemented into computation. Especially in circuit, some researchs still use basic algorithm like fuzzy [1][3][4]. Not all memory can take algorithm with large cost of computation. Fuzzy can be implemented to low-cost memory [7]. This algorithm is very suitable with basic loT especially in simulation stage like activity that is explained in this paper.

\subsection{Sliding modes strategy}

Strategy in mathematical model is necessary to rely the regulation of internal variable, this is not an easy task because minimizing problem always exploits scale model reducing technique. Some factors like accuracy, computational cost, and adaptability has been determined as optimization object in mathematical model for circuit. Sliding modes strategy is a mathematical model that commonly used for electrical circuit. This model is always implemented for optimization in efficient energy [10][13]. More over, control strategy is one of the important aspects in mathematical model. It is because some data inputs that retrieved from sensor are constanly changing [10].

Sliding modes strategy is always related to Lumped Parameter Methods (LMP), this is the best choice because this model orders the certain level of circuits to a model zone and use simplification in different control techniques [11]. The main simplified in sliding modes strategy is reducing the resistors and calculating the parallel resistors (figure 1 ). 


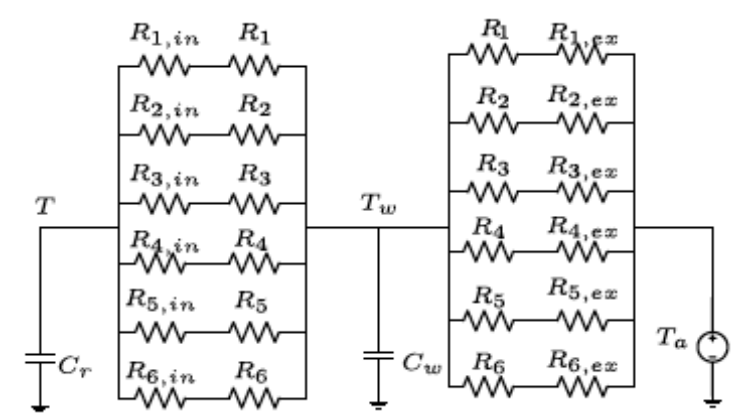

Figure 1. Simplification of model in circuit on Sliding modes strategy

\section{RESEARCH METHOD}

In this activity, we use some hardware as main tools for this loT system, such: Arduino Uno Model, Arduino Tds Meter, HC-SR-04 as ultrasonic sensor, ESP-8266 as network module, water pump, and relay. We use Tsukamoto's Fuzzy Inference System (FIS) which is shown in Fig. 1. Because this system is based on Internet of Thing so the Tsukamoto's is performed on the cloud. It uses self-server which every component like node.js for the service is installed. The general scheme in this system.

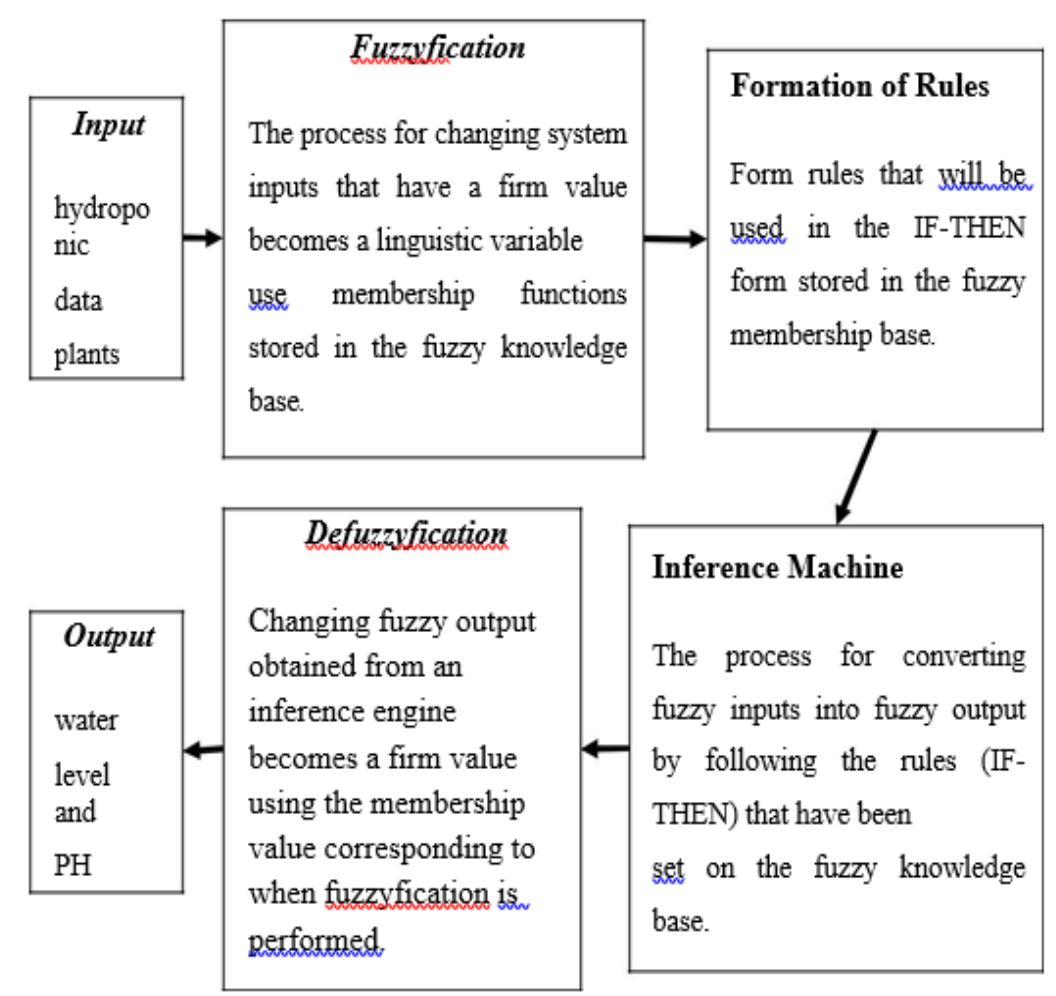

Figure 2. Fuzzy Diagram Process for Monitoring and Controlling in Smart Green Technology

We use spinach plant in hydroponic as experiment object with the standar is shown in Tabel 2. Beside that, to obtain better lighting, the artificial ultraviolet lamp is used to grow the hydroponic well (figure 3). 


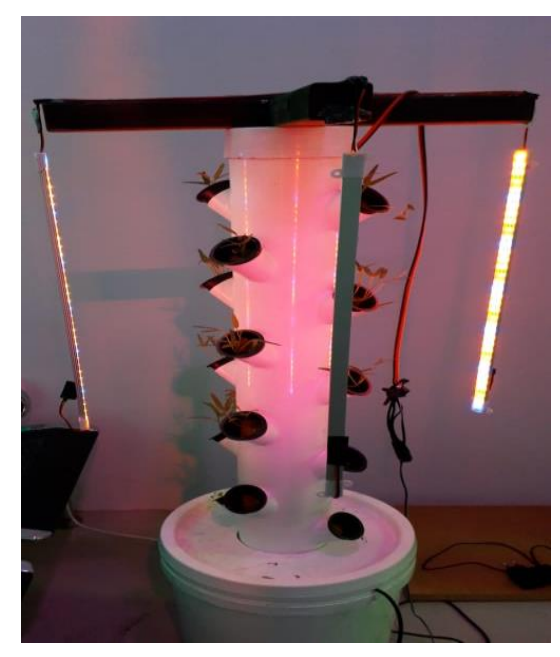

Figure 3. Hydroponic based tower and its lightning system

IOT scheme is set by placing HC-SRO4 ultrasound sensor in hydroponic water tank to measure the water surface, it needs to know when automatic watering system is performed to hydroponic. Another sensor that be placed in hydroponic water tank is TDS meter, this sensor is used to measure nutrition. Those sensor data value is retrieved and processed in loT system to decide when water and or nutrition is given to the plant. Arduino and ESP8266 is placed in a box outside water tank to avoid some disturbance in processing and sending data to internet (figure 4).

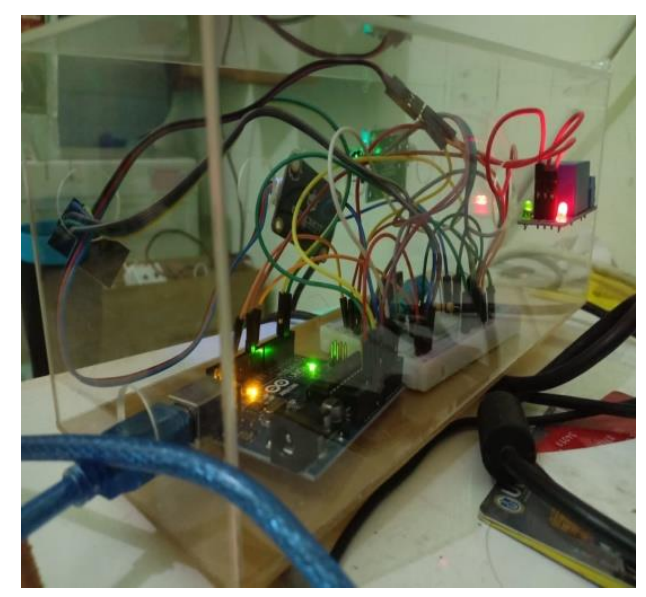

Figure 4. Hardware module installment and placement as data controlling, processing, and transimitting to internet

We use relay to perform water and nutrition control motor. In example, if water is needed to hydroponic, Arduino will tell the port that connected in relay to be active and set the water to be distributed to the plant.

Generally, To get the value of the degree of hydroponic plant membership, a fuzzy set (fuzzyfication) and confirmation (defuzzyfication) are needed as follows: 1) The linear down member membership function is used to present a low fuzzy set; 2) Upright linear membership 
function is used to present a high fuzzy set; 3 ) The triangle membership function is used to present the fuzzy set normal.

In the stage of fuzzification, a fuzzy set and membership function will be formed from symptoms of hydroponic plant. Then rules of formation stage is based from this condition.

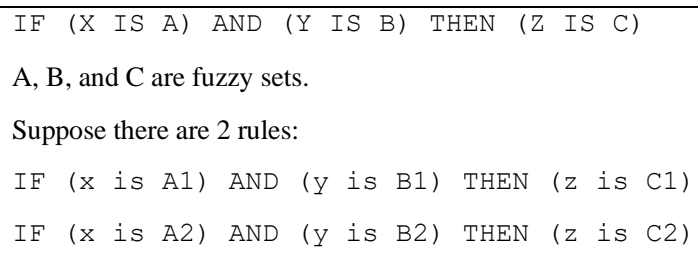

So, if this rule is converted into this problem, then the formula would be like in table 1.

Table 1. Rule Table Used for Calculation

\begin{tabular}{|l|l|}
\hline No. & Rule \\
\hline 1 & IF SN is less and less than that of less healthy plants \\
\hline 2 & IF SN Less AND M According to THEN Unhealthy Plants \\
\hline 3 & IF SN according to AND M less THEN less healthy plants \\
\hline 4 & IF SN According to AND M According to THEN Healthy Plants \\
\hline
\end{tabular}

The functions of the hydroponic plant membership degree are defined by the following equation:

$$
\begin{aligned}
& 090 \leq \mathrm{x} \leq 500 \\
& (\mathrm{x}-500) /(75-500) 500 \leq \mathrm{x} \leq 75 \\
& \mu \operatorname{less}(\mathrm{x})=\{ \\
& (90-x) /(90-75) 75 \leq x \leq 90 \\
& 1 \quad \mathrm{x}=75 \\
& 0 \mathrm{x} \leq 1200 \\
& \mu \operatorname{normal}(\mathrm{x})=\{\quad(\mathrm{x}-1200) /(1000-75) 1200>1000 \\
& 1 \mathrm{x}>1000
\end{aligned}
$$

So, the graph function would be like in the figure $5(a)$ which shows that that the low membership degree has a range of values from 1 to 75 , while the high membership degree lies in the value range of more than 75 values which later becomes the benchmark or basic rule of the value of plants when growing. material for evaluating plants and figure $5(\mathrm{~b})$ which shows the water level function will perform the action when what number is on 1-35 and when the number is above 35 then the function will end and stop it is a fuzzy method applied to hydroponic plants as standard. 


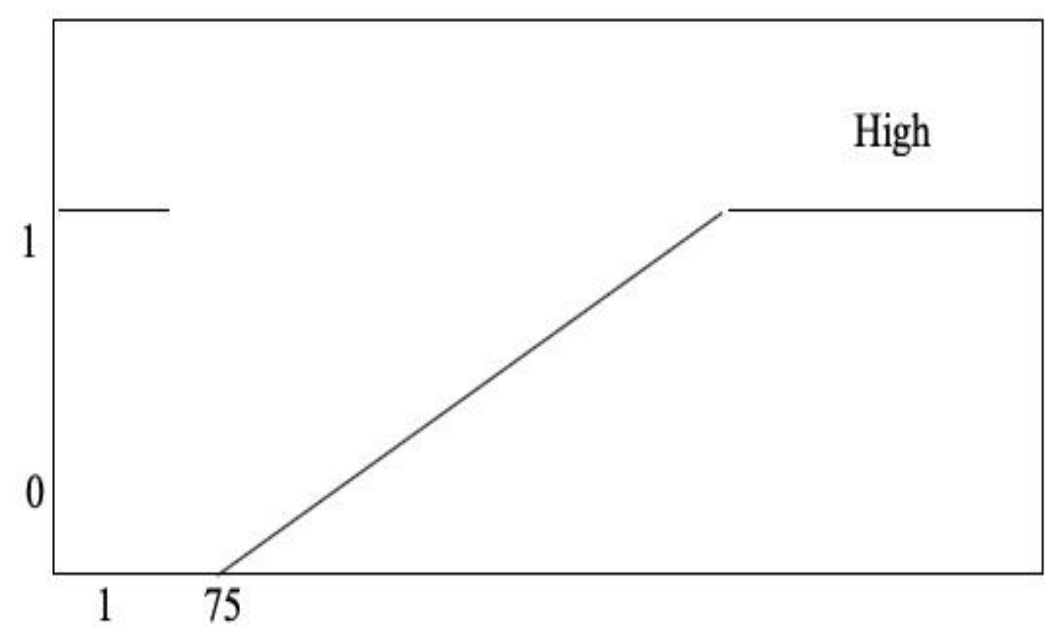

(a)

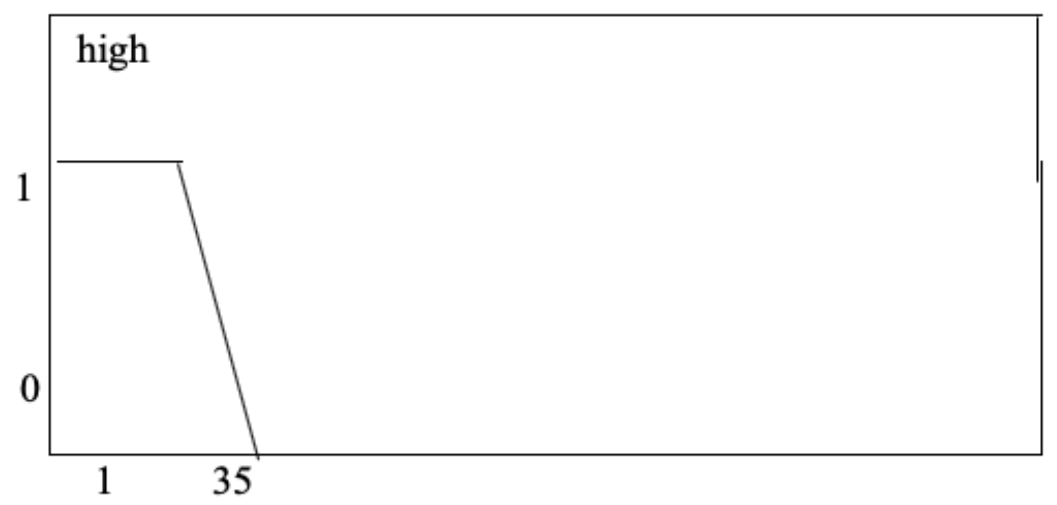

(b)

Figure 5. Membership function in graph: a) nutrition; b) water level

The inference engine uses the MIN implication function to get the $\alpha$-predicate value for each rule $(\alpha 1, \alpha 2, \alpha 3, \ldots \alpha n)$. Then each of these $\alpha$-predicate values is used to calculate the output resulting from the explicit inference (crips) of each rule $(z 1, z 2, z 3, \ldots z n)$. The final output $(z)$ is obtained by using the weighting average: The initial stage is carried out on the subject of hydroponic plants by including the standard nurisi 1200PPM concentration and with a water level of less than $35 \mathrm{CM}$ which is sufficient to show the results as expected. The fuzzification process is based on standard of water hydroponic plants, in this activity we use spinach as sample (table II).

Table 2. Nutrition Standard for Hydroponic Plant

\begin{tabular}{|l|l|l|l|l|}
\hline $\begin{array}{l}\text { Name of } \\
\text { Vegetables }\end{array}$ & Standard Nutrition & $\begin{array}{l}\text { Nutrition day } \\
\text { week }\end{array}$ & $\begin{array}{l}\text { Standard } \\
\text { Ph }\end{array}$ & $\begin{array}{l}\text { Ph day / } \\
\text { week }\end{array}$ \\
\hline $\begin{array}{l}\text { water spinach } \\
\text { plants }\end{array}$ & 534PPM & 5.5 & 7.2 \\
\hline
\end{tabular}

So, the formula would be like 


$$
\begin{gathered}
0 \quad 90 \leq \mathrm{x} \leq 500 \\
(\mathrm{x}-500) /(1050-500) 500 \leq \mathrm{x} \leq 1050
\end{gathered}
$$

$$
(90-\mathrm{x}) /(90-1050) 1050 \leq \mathrm{x} \leq 90
$$

$$
1 \quad \mathrm{x}=1050
$$

$$
\mu \text { Medium spinach }(1050)=1
$$

The defuzzyfication process is carried out as follows:

$$
\begin{aligned}
\mu \operatorname{Max}=(\mathrm{z}-90) /(500-90) & =1 \\
\mathrm{z} & =500 \\
\mu \operatorname{Min}=(500-\mathrm{z}) /(500-90) & =1 \\
\mathrm{z} & =90 \\
\mathrm{z}=(1 * 500) / 1+(1 * 90) / 1 & \\
\mathrm{z}=295 \text { (low) } &
\end{aligned}
$$

To test this system, a comparing result from manual measurements using TDS meters is used. After getting the final results, an accuracy test is carried out in the form of a percentage. The system testing process uses formula level accuracy.

$$
\text { Level of accuracy }(100 \%)=X 100 \%
$$

Where $\mathrm{X}$ is the number of classifications that the system actually performs on the actual data and $\mathrm{N}$ is the number of all data tested.

Realistically, this activity uses the nutrition of ab mix which is a mixture of nutrients A and nutrition $B$ the use of these nutrients is based on general standards of the ministry of agriculture, so to get better measurement we use several characteristics about what condition an hydroponic plants grow well such: adequate nutrition; brightness of the environment; water temperature; no pest in plant; and adequate of air circulation. Based on table 1, The following are the production rules in identifying hydroponic plant conditions based on various conditions, such:

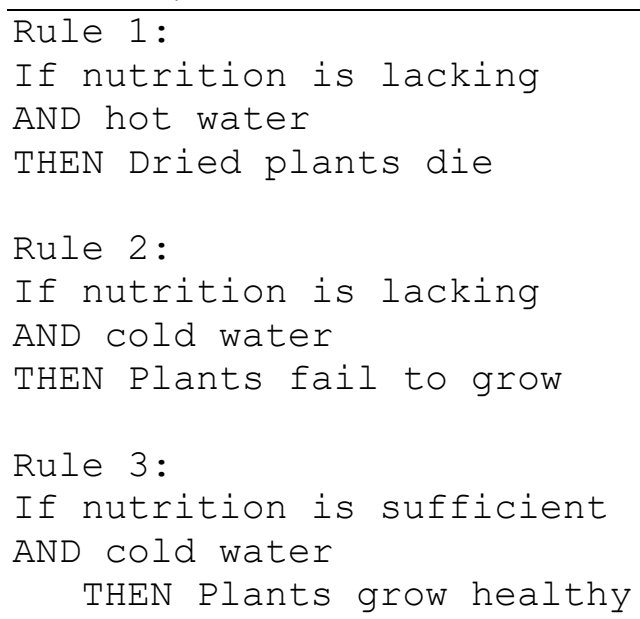

\section{RESULTS AND DISCUSSION}

Based on our experiment, the sliding modes strategy has given better result than nonusing sliding modes strategy. Figure 6 shows the result, it can be described that effect of sliding 
modes strategy is more stable than no sliding modes strategy. A unique phenomenon from this graph is the gap is quite small, some data point from non-sliding modes strategy have passed the data from sliding modes strategy.

\section{WATER NUTRITION CONTROLLING RESULT}

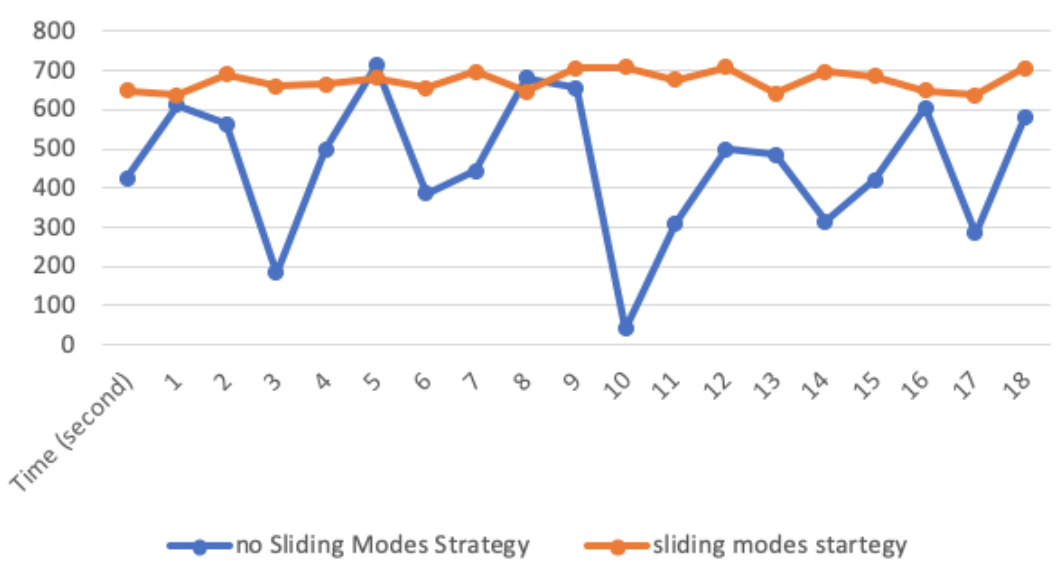

Figure 6. Difference result between sliding modes strategy and no sliding modes strategy.

\section{CONCLUSION}

Although we have got more stable result, the data value is still not rapid (about 600 700). However, this condition is still not adapatable with plant condition so it is still harm for the plant. In next activity, we would develop an adaptable method and a new technique to realize it.

\section{REFERENCES}

[1] V. K S and R. R. Neeralagi, "IoT based Health Monitoring using Fuzzy logic," Int. J. Comput. Intell. Res., vol. 13, no. 10, pp. 2419-2429, 2017.

[2] M. I. Mahali, "Smart Door Locks based on Internet of Things Concept with Mobile Backend as a Service," J. Electron. Informatics, Vocat. Educ., vol. 1, no. November, pp. 171-181, 2016.

[3] N. Gligorić, T. Dimčić, S. Krčo, and V. Dimčić, "Internet of Things Enabled LED Lamp Controlled by Satisfaction of Students in a Classroom," in A publication of IPSI Bgd Internet Research Society New York, 2014.

[4] S. Tembe, S. Khan, and R. Acharekar, "IoT based Automated Hydroponics System," Int. J. Sci. Eng. Res., vol. 9, no. 2, pp. 67-71, 2018.

[5] D. Komaludin, "Penerapan Teknologi Internet of Thing (IoT) pada Bisnis Budidaya Tanaman Hidroponik sebagai Langkah Efisiensi Biaya Perawatan," in Festival Riset IImiah Manajemen \& Akuntansi, 2018, pp. 682-690.

[6] P. N. Crisnapati, I. N. K. Wardana, I. K. Agus, A. Aryanto, and A. Hermawan, "Hommons: Hydroponic Management and Monitoring System for an IOT Based NFT Farm Using Web Technology," in 2017 5th International Conference on Cyber and IT Service Management (CITSM), 2017, no. March 2018, pp. 1-6. 
[7] M. Naufal, R. Ibrahim, M. Solahudin, and S. Widodo, "Control System for Nutrient Solution of Nutrient Film Technique Using Fuzzy Logic," TELKOMNIKA, vol. 13, no. 4, 2015.

[8] M. Prathisthaya, Liyantono, and M. Solahudin, "Rancang Bangun Sistem Kendali Proportional Integral- Deritative pada Pengendalian Konsentrasi Larutan Nutrisi Hidroponik," in Proceedings of the National Seminar FTIP UNPAD - PERTETA - HIPI 2014, 2014, pp. 376-384.

[9] Chen, S.Y.; Gong, S.S. Speed tracking control of pneumatic motor servo systems using observation-based adaptative dynamic sliding-mode control. Mech. Syst. Signal Process. 2017, 94, 111-128.

[10] Huang, Y.; Khajepour, A.; Ding, H.; Bagheri, F.; Bahrami, M. An energy-saving set-point optimizer with a sliding mode controller for automotive air-conditioning/refrigeration systems. Appl. Energy 2017, 188, 576-585.

[11] Mironova, A.; Mercorelli, P.; Zedler, A.; Mironova, A.; Mercorelli, P. Robust Control using Sliding Mode Approach for Ice-Clamping Device activated by Thermoelectric Coolers. Int. Fed. Autom. Control 2016, 25, 470-475.

[12] Norton, M.; Khoo, S.; Kouzani, A.; Stojcevski, A. Adaptive fuzzy multi-surface sliding control of multiple-input and multiple-output autonomous flight systems. IET Control Theory Appl. 2015, 9, 587-597.

[13] He, T.; Li, L.; Zhu, J.; Zheng, L. A Novel Model Predictive Sliding Mode Control for AC/DC Converters with Output Voltage and Load Resistance Variations. In Proceedings of the 2016 IEEE Energy Conversion Congress and Exposition (ECCE), Milwaukee, WI, USA, 18-22 September 2016; pp. 1-6. 